\title{
Valuing knowledge on temporal dynamics from long-term monitored basins for neighbouring sites
}

\author{
A. DE LAVENNE ${ }^{1,2}$, C. CUDENNEC ${ }^{1,2}$, O. FOVET ${ }^{2,1}$ \& L. RUIZ ${ }^{2,1}$ \\ 1 AGROCAMPUS OUEST, UMR1069, Sol Agro et hydrosystème Spatialisation, F-35000 Rennes, France \\ a.lavenne@gmail.com \\ 2 INRA, UMR1069, Sol Agro et hydrosystème Spatialisation, F-35000 Rennes, France
}

\section{LONG-TERM MONITORED BASINS AS IMPORTANT SOURCES OF KNOWLEDGE}

Long-term monitored stations are important investments (of time, money and labour) which enable the evaluation of hydrological responses over the years. An example is the Coët-Dan basin near the city of Naizin (ORE AgrHys, Brittany, France) which has been instrumented since 1992 by INRA, www6.inra.fr/ore agrhys eng/. The project is focused on multi-scale temporal variation of water and solute transfers under the effects of agriculture and climate. The knowledge produced has improved our understanding of hydrological processes (Aubert et al. 2013), but such stations can also be directly useful to comprehend the water security issues of surrounding basins, thus tackling the challenges of both Panta Rhei and PUB (Hrachowitz et al. 2013, Montanari et al. 2013).

\section{GENERALIZING HYDROLOGICAL KNOWLEDGE TO SURROUNDING BASINS}

We propose to apply a methodology which enables the transposition of hydrographs measured in gauged stations to ungauged stations. The gauged station is the long-term monitored basin of the Coët-Dan River and is used to simulate the hydrographs of five surrounding basins of the Blavet and the Oust rivers (Fig. 1). The hydrograph transposition follows three main steps (Fig. 2).

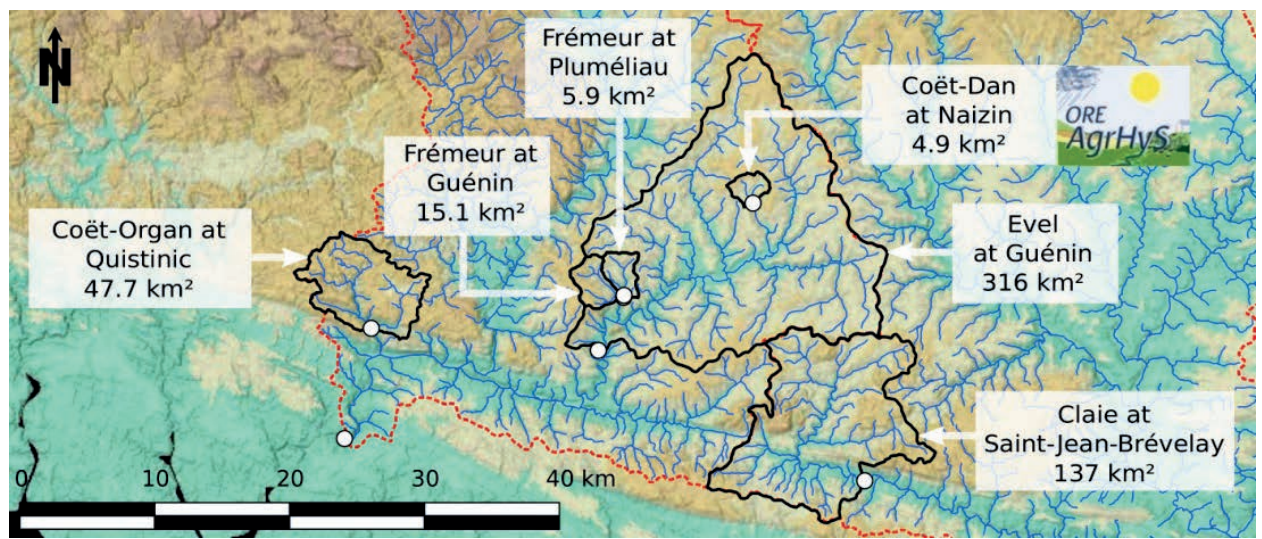

Fig. 1 Map of the studied basins surrounding the Coët-Dan at Naizin long-term monitored basin.

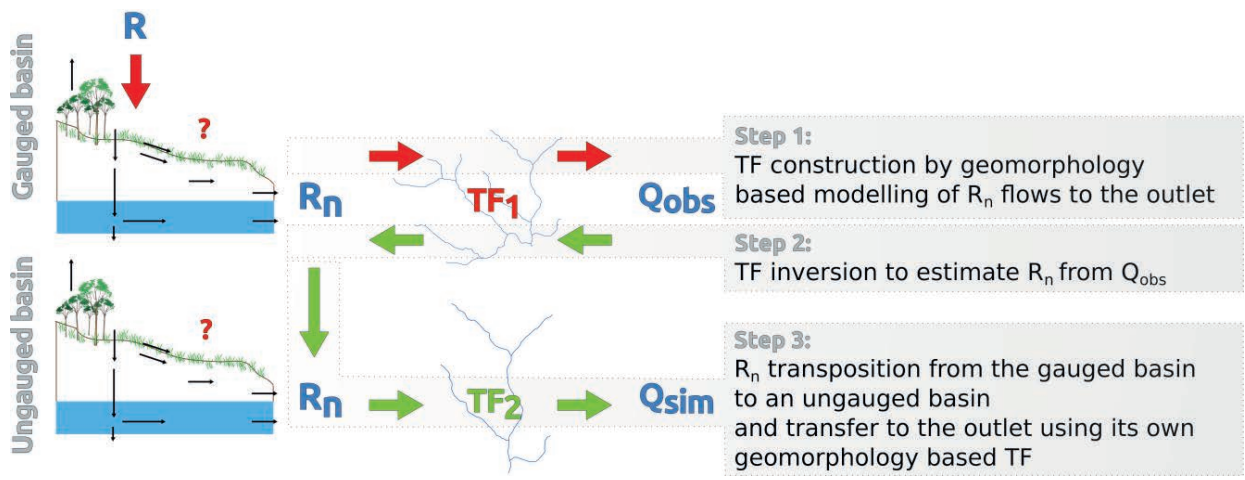

Fig. 2 Methodology of hydrograph transposition (from de Lavenne et al. 2014) 
Firstly, a geomorphology-based model of the flow transfer by the stream network is built from the analysis of the flow path lengths through the stream network to the outlet (Cudennec and de Lavenne 2015). The probability density function ( $p d f)$ of those flow distances are used to assess the $p d f$ of the travel time to the outlet $p d f(t)$. This is done by estimating the flow velocity from the ratio of the mean flow distance over the median rise time of events detected between 1990 and 2010 (de Lavenne 2013). The assessed transfer function of the unit hydrograph type $p d f(t)=\mathrm{TF}(t)$ allows estimation of the discharge at the outlet $Q\left(\mathrm{~m}^{3} \cdot \mathrm{s}^{-1}\right)$ from a convolution described by equation (1):

$$
Q(t)=S \times R_{\mathrm{n}} \times \mathrm{TF}(t)
$$

where $t(\mathrm{~s})$ is the time, $S\left(\mathrm{~m}^{2}\right)$ is the basin's surface area and $R_{\mathrm{n}}(\mathrm{m})$ is the net rainfall.

Secondly, by inversing the transfer function $\operatorname{TF}(t)$, the net rainfall $R_{\mathrm{n}}$ is assessed from the streamflow measurement. This work is based on previous studies (Boudhraâ et al. 2006, 2009), and according to the inverse problems theory (Tarantola and Valette 1982).

Thirdly, the net rainfall of the gauged basin is transposed to the ungauged basin, where it can be reconvoluted with its own transfer function to estimate its own hydrograph. Performances of simulations (Table 1), assessed from gauged to gauged basins, demonstrate the relevance regardless of the sizes of the basins (for instance, transpositions to Evel at Guénin).

Table 1 Performance of simulations when transposing Coët-Dan at Naizin hydrograph to five surrounding basins. The median goodness of fit is presented for 12 periods of simulations of two months (Nov.-Dec. and May-June) between 2006 and 2012, using three different criteria: Nash-Sutcliffe efficiency (NSE), Pearson Correlation coefficient (r) and Percent Bias (pbias).

\begin{tabular}{llllll}
\hline & $\begin{array}{l}\text { Frémeur at } \\
\text { Pluméliau }\end{array}$ & $\begin{array}{l}\text { Frémeur at } \\
\text { Guénin }\end{array}$ & $\begin{array}{l}\text { Coët-Organ at } \\
\text { Quistinic }\end{array}$ & $\begin{array}{l}\text { Claie at Saint- } \\
\text { Jean-Brévelay }\end{array}$ & $\begin{array}{l}\text { Evel at } \\
\text { Guénin }\end{array}$ \\
\hline NSE & 0.275 & 0.095 & -1.415 & -0.335 & 0.705 \\
$\mathrm{r}$ & 0.875 & 0.865 & 0.87 & 0.9 & 0.96 \\
pbias & -42.6 & -47.4 & -56.75 & -49.3 & -25 \\
\hline
\end{tabular}

\section{POTENTIAL OF LONG-TERM MONITORED BASINS FOR WATER SECURITY}

This work illustrates a methodology which has potential for generalizing hydrological and hydrochemical knowledge produced on a long-term monitored basin. Our measurement and understanding of the system, such as the multi-scale temporal dynamics, from the hydrological event to the historical agro-hydrological trajectory of the basin, can be transferred to surrounding points of interest and be used to provide information about any water security issue (peak flow timing and value, resilience of the system after water pollution, efficiency and inertia and mitigation actions, etc.).

\section{REFERENCES}

Aubert, A.H., et al. (2013) Solute transport dynamics in small, shallow groundwater-dominated agricultural catchments: insights from a high-frequency, multisolute $10 \mathrm{yr}-$ long monitoring study. Hydrol. Earth Syst. Sci. 17, $1379-1391$.

Boudhraâ, H., et al. (2006) Inversion d'une modelisation de type hydrogramme unitaire à base géomorphologique: interprétation physique et première mise en œuvre. In: Sivapalan, M. et al. (eds) Prediction in Ungauged Basins: Promises and Progress. IAHS Publ. 303, 391-399.

Boudhraâ, H., et al. (2009) Hydrograph transposition between basins through a geomorphology-based deconvolutionreconvolution approach. In: Yilmaz, K.K. et al. (eds) New Approaches to Hydrological prediction in Data-sparse Regions IAHS Publ. 333, 76-83.

Cudennec, C. and de Lavenne, A. (2015) Editorial: Hydrogeomorphology - a long-term scientific interface. Hydrol. Res. (in press). doi:10.2166/nh.2015.100

Hrachowitz M., et al. (2013) A decade of Predictions in Ungauged Basins (PUB) - a review. Hydrol. Sci. J. 58(6), 1198-1255.

de Lavenne, A. (2013) Modélisation hydrologique à base géomorphologique de bassins versants non jaugés par régionalisation et transposition d'hydrogramme, Ph.D. thesis, Agrocampus Ouest Rennes, France.

de Lavenne, A., Boudhraâ, H. and Cudennec, C. (2015) Streamflow prediction in ungauged basins through geomorphologybased hydrograph transposition. Hydrol. Res. doi:10.2166/nh.2013.099

Montanari, A., et al. (2013) "Panta Rhei - Everything Flows": Change in hydrology and society - The IAHS Scientific Decade 2013-2022. Hydrol. Sci. J. 58(6), 1256-1275.

Tarantola, A. and Valette, B. (1982) Inverse problems = quest for information, J. Geophys. 50, 150-170. 